\title{
The Influences of Catalysts and Co-catalysts on the Thermal Decomposition of Potassium Peroxydisulphate in Aqueous Solution at $70^{\circ} \mathrm{C}$
}

\author{
M. J. A. Abualreish ${ }^{1,2}$ \\ ${ }^{1}$ Department of Chemistry, Faculty of Science, Northern Boarders University, Arar, Kingdom of Saudi Arabia (current address) \\ ${ }^{2}$ Department of Chemistry, Faculty of Science and Technology, Omdurman Islamic University, Sudan (permanent address)
}

\begin{abstract}
The thermal decomposition of potassium peroxydisulphate at $70^{\circ} \mathrm{C}$ under catalyzed conditions was investigated. The decomposition was catalyzed by different systems namely, the silver (I) ion, the copper (II) ion and in the presence of both ions (co- catalysts). It is obvious that the presence of small amount of silver(I) or copper (II) ion enhance the rate of decomposition of peroxydisulphate. A systematic kinetic study showed that the catalytic influence of the different systems used in the decomposition is in the following order :co-catalyst $>\mathrm{Ag}^{+}>\mathrm{Cu}^{2+}$.
\end{abstract}

Keywords Thermal Decomposition, Potassium Peroxydisulphate, Co-catalyst

\section{Introduction}

The thermal decomposition of potassium peroxydisulphate was the subject of study of many workers [1-3], they all suggested that the decomposition follows a first order kinetics. Early workers [4], studying the thermal decomposition of potassium peroxydisulphate found that the decomposition in aqueous solution was accelerated by rise of temperature and depends on the concentration of solution. Levr and Migliorini [5] have found that the thermal decomposition of potassium peroxydisulphate was unimolecular and is catalyzed by acid. The silver ion catalysed decomposition of peroxydisulphate ion was studied by Bawn and Margrerison [6], their studies showed that the decomposition is first order in both silver and peroxydisulphate ion. Abualreish [7] studied the uncatalyzed thermal decomposition of potassium peroxydisulphate. He found that the decomposition is first order in peroxydisulphate concentration and satisfies the relation:

$\mathrm{R}=\mathrm{K}_{\mathrm{O}}\left[\mathrm{S}_{2} \mathrm{O}_{8}{ }^{2-}\right]_{\mathrm{O}}$ the value the observed rate constant $\mathrm{k}_{\mathrm{o}}$ equal to $0.54 \times 10^{-5} \mathrm{sec}^{-1}$. Bartlett and Cottman [8] have suggested that the radicals produced in the Peroxydisulphate ion decomposition in aqueous solution cannot induce the decomposition of the ion and that autocatalysis is not observed in the thermal decomposition of peroxydisulphate.

\section{Experimental}

* Corresponding author:

mustjeed_2008@hotmail.com (M. J. A. Abualreish)

Published online at http://journal.sapub.org/chemistry

Copyright (C) 2012 Scientific \& Academic Publishing. All Rights Reserved
All chemicals used were AnalaR grade. All solutions were prepared according to the usual analytical procedures. Deionized water was used in all kinetic runs. Since the reaction does not take place to any measurable extent at room temperature $\left(t_{1 / 2}=\right.$ one month) [9], the temperature used was $70{ }^{\circ} \mathrm{C}$. The iodometric method was used for the analysis and estimation of unreacted peroxydisulphate $\left[\mathrm{S}_{2} \mathrm{O}_{8}{ }^{2-}\right]$ which is a modification of the method used by Bartlett and Cottman [8] and Rosin [10]. In this method to $5 \mathrm{ml}$ of the reaction mixture, $5 \mathrm{ml}$ sodium bicarbonate and one $\mathrm{ml}$ of sulphuric acid were added to maintain a $\mathrm{pH}$ value of 7.1 to 7.2 . The liberated iodine was titrated against sodium thiosulphate using starch as indicator.

\section{Results and discussion}

For many reducing agents. oxidation by peroxydisulphate does not proceed at a convenient rate at $25{ }^{\circ} \mathrm{C}$, unless a catalyst is present. The most thoroughly investigated catalyst is the silver (I) ion [11], although reactions involving the copper (II) ion [12] and the iron (II) ion [13] also have been studied. Dependence of the rate of decomposition of peroxydisulphate on the systems: $\left[\mathrm{Ag}^{+}\right],\left[\mathrm{Cu}^{2+}\right]$ and $\left[\mathrm{Ag}^{+}+\right.$ $\left.\mathrm{Cu}^{2+}\right]$ : Tables (1), (2) and (3) show the catalytic effect of $\mathrm{Ag}(\mathrm{I}), \mathrm{Cu}(\mathrm{II})$ and $[\mathrm{Ag}(\mathrm{I})+\mathrm{Cu}(\mathrm{II})]$ ions on the thermal decomposition of potassium peroxydisulphate at $70^{\circ} \mathrm{C}$ in which the concentration of $\mathrm{Ag}(\mathrm{I}), \mathrm{Cu}(\mathrm{II})$ and $[\mathrm{Ag}(\mathrm{I})+\mathrm{Cu}(\mathrm{II})]$ ions varies from 0.01 to 0.1 mole/ 1 while that of peroxydisulphate was kept constant at 0.01 mole/l. Results were represented graphically in figures (1) and (2) for $\mathrm{Ag}(\mathrm{I})$ ion, (3) and (4) for $\mathrm{Cu}(\mathrm{II})$ ion and (5)and (6) for $[\mathrm{Ag}(\mathrm{I})+$ $\mathrm{Cu}(\mathrm{II})]$ ion. 
Table 1. Dependence of the rate of decomposition of peroxydisulphate on $\operatorname{Ag}(\mathrm{I})$ ion

\begin{tabular}{|c|c|c|c|}
\hline \begin{tabular}{c}
{$\left[\begin{array}{c}\left.\mathrm{AgNO}_{3}\right]_{\mathrm{o}} \\
\mathrm{mole} / 1\end{array}\right.$} \\
\hline 0.01
\end{tabular} & $\begin{array}{c}{\left[\mathrm{S}_{2} \mathrm{O}_{8}{ }^{2-}\right]_{\text {Aver }}} \\
\text { mole } / 1\end{array}$ & $\begin{array}{c}10^{6} \mathrm{R} \\
\mathrm{mole} / 1 / \mathrm{sec}\end{array}$ & $\begin{array}{c}10^{5} \mathrm{k}_{\mathrm{o}} \\
\mathrm{sec}^{-1}\end{array}$ \\
\hline 0.02 & 0.00884 & 0.3000 & 3.41 \\
\hline 0.03 & 0.00861 & 0.4028 & 4.29 \\
\hline 0.04 & 0.00819 & 0.4736 & 5.80 \\
\hline 0.05 & 0.00742 & 0.6361 & 8.81 \\
\hline 0.06 & 0.00686 & 0.8264 & 11.41 \\
\hline 0.08 & 0.00652 & 0.8486 & 13.35 \\
\hline 0.1 & 0.00580 & 0.9861 & 17.50 \\
\hline & & 1.1222 & 22.36 \\
\hline
\end{tabular}

Table 2. Dependence of the rate of decomposition of peroxydisulphate on $\mathrm{Cu}(\mathrm{II})$ ion

\begin{tabular}{|c|c|c|c|}
\hline $\begin{array}{c}{\left[\mathrm{CuSO}_{4}\right]_{\mathrm{o}}} \\
\mathrm{mole} / 1\end{array}$ & $\begin{array}{c}{\left[\mathrm{S}_{2} \mathrm{O}_{8}{ }^{2-}\right]_{\text {Aver }}} \\
\text { mole/l }\end{array}$ & $\begin{array}{c}10^{6} \mathrm{R} \\
\mathrm{mole} / 1 / \mathrm{sec}\end{array}$ & $\begin{array}{c}10^{5} \mathrm{k}_{\mathrm{o}} \\
\mathrm{sec}^{-1}\end{array}$ \\
\hline 0.01 & 0.00885 & 0.2986 & 3.39 \\
\hline 0.02 & 0.00868 & 0.3208 & 4.12 \\
\hline 0.03 & 0.00820 & 0.4694 & 5.75 \\
\hline 0.04 & 0.00745 & 0.6681 & 8.64 \\
\hline 0.05 & 0.00693 & 0.8083 & 11.08 \\
\hline 0.06 & 0.00655 & 0.8417 & 13.21 \\
\hline 0.08 & 0.00586 & 0.8611 & 17.11 \\
\hline 0.1 & 0.00514 & 0.9750 & 22.33 \\
\hline
\end{tabular}

Table 3. Dependence of the rate of decomposition of peroxydisulphate on $[\mathrm{Ag}(\mathrm{I})+\mathrm{Cu}(\mathrm{II})]$ ion

\begin{tabular}{|c|c|c|c|}
\hline $\begin{array}{c}{\left[\mathrm{AgNO}_{3}\right]_{\mathrm{o}}=} \\
{\left[\mathrm{CuSO}_{4}\right]_{\mathrm{o}}} \\
\mathrm{mole} / 1\end{array}$ & $\begin{array}{c}{\left[\mathrm{S}_{2} \mathrm{O}_{8}{ }^{2-}\right]_{\mathrm{o}}} \\
\mathrm{mole} / 1\end{array}$ & $\begin{array}{c}10^{6} \mathrm{R} \\
\mathrm{mole} / 1 / \mathrm{sec}\end{array}$ & $\begin{array}{c}10^{5} \mathrm{k}_{\mathrm{o}} \\
\mathrm{sec}^{-1}\end{array}$ \\
\hline 0.01 & 0.00436 & 0.7073 & 20.39 \\
\hline 0.02 & 0.00483 & 0.7167 & 20.17 \\
\hline 0.03 & 0.00419 & 0.7312 & 21.48 \\
\hline 0.04 & 0.00392 & 0.7750 & 23.11 \\
\hline 0.05 & 0.00360 & 0.8135 & 22.94 \\
\hline 0.06 & 0.00345 & 0.8260 & 22.96 \\
\hline 0.08 & 0.00437 & 0.8813 & 22.06 \\
\hline 0.1 & 0.00398 & 0.9219 & 24.20 \\
\hline
\end{tabular}

Figures (1) and (3), show that the value of $\mathrm{k}_{\mathrm{o}}$ increases linearly with the increasing concentration of $\mathrm{Ag}$ (I) and $\mathrm{Cu}$ (II) ions respectively, indicating first order dependence of the reaction on the catalyst concentration. In the case of the system $\left[\mathrm{Ag}^{+}+\mathrm{Cu}^{2+}\right]$ (figure (5)), the value of $\mathrm{k}_{\mathrm{o}}$ does not increases linearly with the increasing concentration of $\left[\mathrm{Ag}^{+}\right.$ $+\mathrm{Cu}^{2+}$ ]. It that means the value of $\mathrm{k}_{\mathrm{o}}$ is independent of the initial co- catalyst concentration.

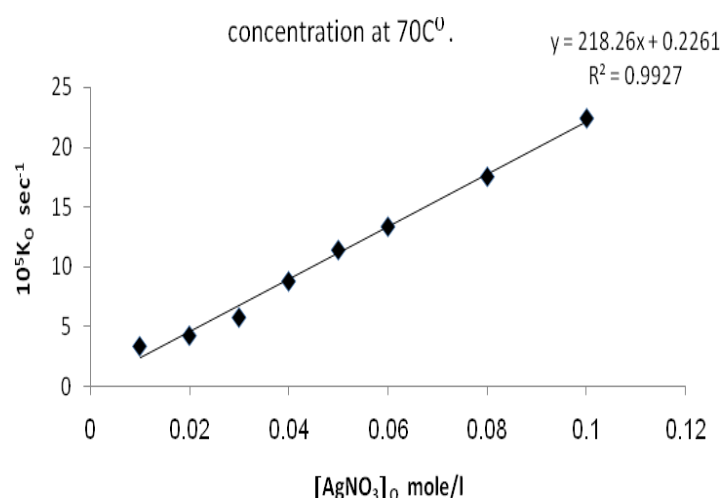

Figure 1. Observed rate dependence on $\mathrm{Ag}^{+}$ion concentration at $70{ }^{\circ} \mathrm{C}$

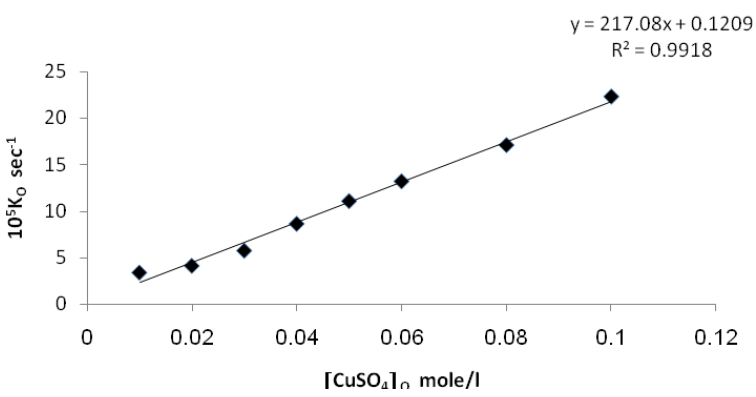

Figure 3. Observed rate dependence on $\mathrm{Cu}^{++}$ion concentration at $70^{\circ} \mathrm{C}$

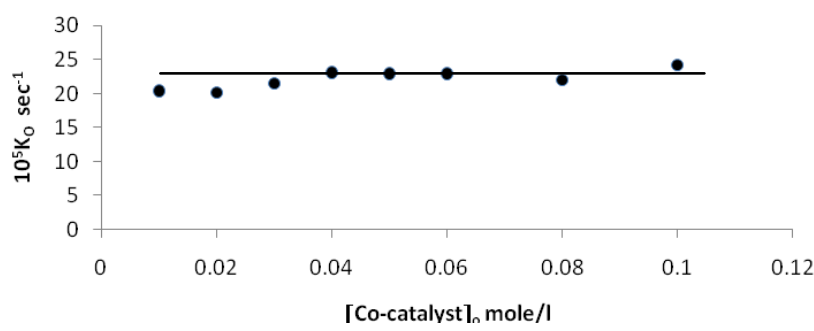

Figure 5. Plot of the observed rate constant ko against [Co-catalyst $]_{\mathrm{o}}$ at $70^{\circ} \mathrm{C}$

From figures (2), (4), and (6) the intercept at the rate axis is equal to $0.25 \times 10^{-6} \mathrm{~mole} / \mathrm{l} / \mathrm{sec}$ for $\mathrm{Ag}(\mathrm{I}), 0.23 \times 10^{-6}$ $\mathrm{mole} / \mathrm{l} / \mathrm{sec}$ for $\mathrm{Cu}(\mathrm{II})$, and $0.67 \times 10^{-6} \mathrm{~mole} / \mathrm{l} / \mathrm{sec}$ for

$[\mathrm{Ag}(\mathrm{I})+\mathrm{Cu}(\mathrm{II})]$ ion. Therefore the observed first order rate law for the three systems can be expressed as follows :

$$
\begin{aligned}
& \mathrm{R}=0.25 \times 10^{-6}+\mathrm{k}_{\mathrm{o}}\left[\mathrm{Ag}^{+}\right]_{\mathrm{o}} \\
& \mathrm{R}=0.23 \times 10^{-6}+\mathrm{k}_{\mathrm{o}}\left[\mathrm{Cu}^{2+}\right]_{\mathrm{o}} \\
& \mathrm{R}=0.67 \times 10^{-6}+\mathrm{k}_{\mathrm{o}}\left[\mathrm{Ag}^{+}+\mathrm{Cu}^{2+}\right]_{\mathrm{o}}
\end{aligned}
$$

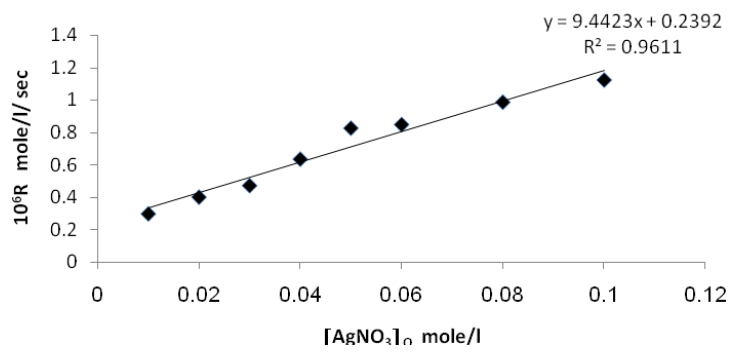

Figure 2. Rate dependence on $\mathrm{Ag}^{+}$ion concentration at $70{ }^{\circ} \mathrm{C}$

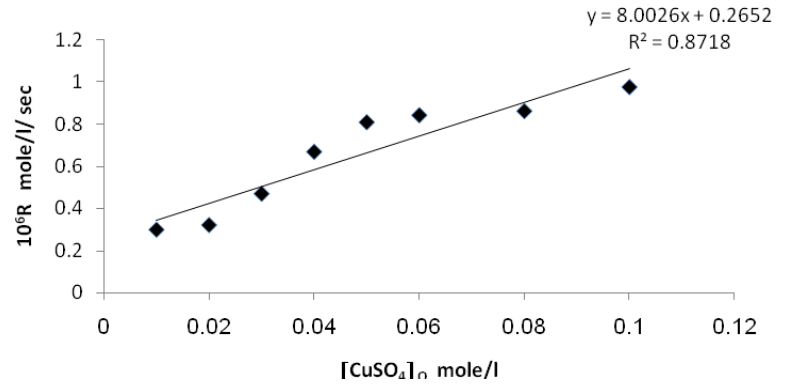

Figure 4. Rate dependence on $\mathrm{Cu}^{++}$ion concentration at $70{ }^{\circ} \mathrm{C}$ 


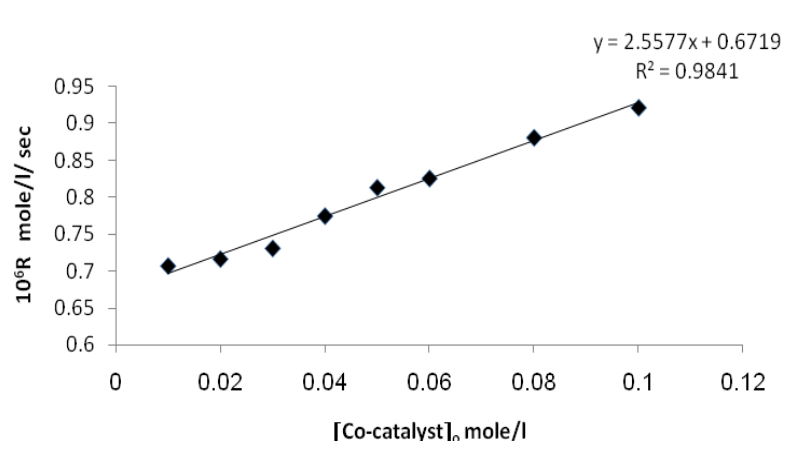

Figure 6. Plot of the rate R against $[\text { Co-catalyst }]_{0}$ at $70{ }^{\circ} \mathrm{C}$

The reactions were also studied at various peroxydisulphate concentrations and constant $\left[\mathrm{Ag}^{+}\right],\left[\mathrm{Cu}^{2+}\right]$ and $\left[\mathrm{Ag}^{+}+\mathrm{Cu}^{2+}\right]$ concentrations . Results are shown in tables (4), (5) and (6) and represented graphically in figures (7) and (8) for $\mathrm{Ag}(\mathrm{I})$ ion, (9) and (10) for $\mathrm{Cu}(\mathrm{II})$ ion and (11) and (12) for $[\mathrm{Ag}(\mathrm{I})+\mathrm{Cu}(\mathrm{II})]$ ions.

Table 4. Peroxydisulphate dependence : $\left[\mathrm{AgNO}_{3}\right]_{\mathrm{o}}=0.01 \mathrm{~mole} / 1 \mathrm{Temp}$. $70^{\circ} \mathrm{C}$

\begin{tabular}{|c|c|c|c|}
\hline $\begin{array}{c}{\left[\mathrm{S}_{2} \mathrm{O}_{8}{ }^{2-}\right]_{\mathrm{o}}} \\
\text { mole/l }\end{array}$ & $\begin{array}{c}\left.\mathrm{S}_{2} \mathrm{O}_{8}{ }^{2-}\right]_{\text {Aver }} \\
\text { mole/l }\end{array}$ & $\begin{array}{c}10^{6} \mathrm{R} \\
\mathrm{mole} / \mathrm{l} / \mathrm{sec}\end{array}$ & $\begin{array}{l}10^{5} \mathrm{k}_{\mathrm{o}} \\
\mathrm{sec}^{-1}\end{array}$ \\
\hline 0.01 & 0.00841 & 0.3000 & 3.41 \\
\hline 0.02 & 0.01816 & 0.4847 & 2.76 \\
\hline 0.03 & 0.02704 & 0.8111 & 3.03 \\
\hline 0.04 & 0.03607 & 1.0958 & 2.86 \\
\hline 0.05 & 0.04575 & 1.1264 & 2.54 \\
\hline 0.06 & 0.05477 & 1.6069 & 2.61 \\
\hline 0.08 & 0.07257 & 2.0542 & 2.76 \\
\hline 0.1 & 0.0915 & 2.3459 & 2.49 \\
\hline
\end{tabular}

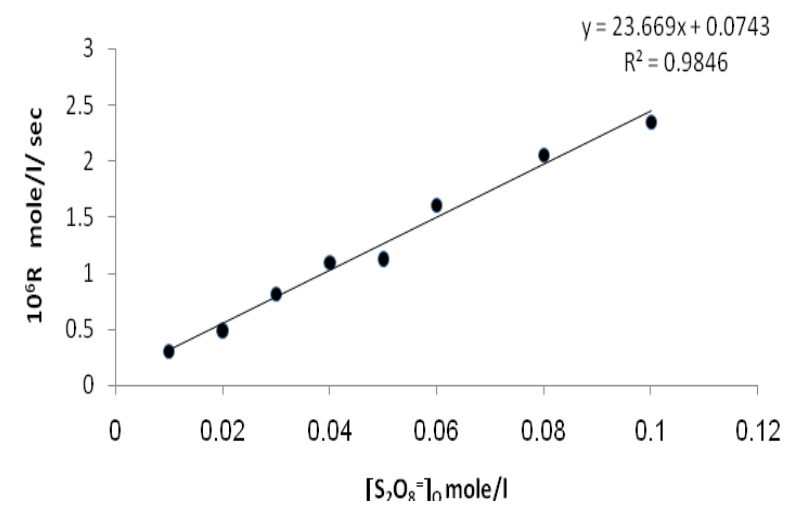

Figure 7. Rate dependence on $\left[\mathrm{S}_{2} \mathrm{O}_{8}{ }^{\circ}\right]_{0}$ at $70{ }^{\circ} \mathrm{C}$

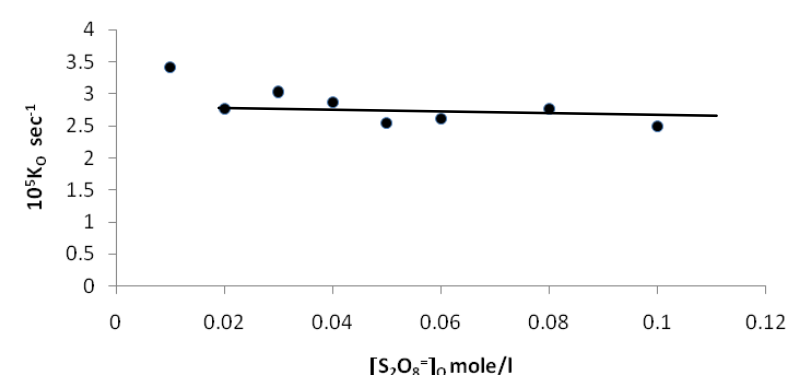

Figure 8. Plot of the observed rate constant Ko against $\left[\mathrm{S}_{2} \mathrm{O}_{8}{ }^{\circ}\right]_{\mathrm{o}}$ at $70{ }^{\circ} \mathrm{C}$
Table 5. Peroxydisulphate dependence : $\left[\mathrm{CuSO}_{4}\right]_{\mathrm{o}}=0.01 \mathrm{~mole} / 1$ Temp. $70^{\circ} \mathrm{C}$

\begin{tabular}{|c|c|c|c|}
\hline $\begin{array}{c}{\left[\mathrm{S}_{2} \mathrm{O}_{8}{ }^{2-}\right]_{\mathrm{o}}} \\
\mathrm{mole} / 1\end{array}$ & $\begin{array}{c}{\left[\mathrm{S}_{2} \mathrm{O}_{8}{ }^{2-}\right]_{\text {Aver }}} \\
\text { mole/l }\end{array}$ & $\begin{array}{c}10^{6} \mathrm{R} \\
\mathrm{mole} / 1 / \mathrm{sec}\end{array}$ & $\begin{array}{c}10^{5} \mathrm{k}_{\mathrm{o}} \\
\mathrm{sec}^{-1}\end{array}$ \\
\hline 0.01 & 0.00885 & 0.3000 & 3.41 \\
\hline 0.02 & 0.01817 & 0.4847 & 2.76 \\
\hline 0.03 & 0.02706 & 0.8111 & 3.03 \\
\hline 0.04 & 0.03634 & 1.0958 & 2.86 \\
\hline 0.05 & 0.04573 & 1.1264 & 2.54 \\
\hline 0.06 & 0.05489 & 1.6069 & 2.61 \\
\hline 0.08 & 0.07267 & 2.0542 & 2.76 \\
\hline 0.1 & 0.07814 & 2.3459 & 2.49 \\
\hline
\end{tabular}

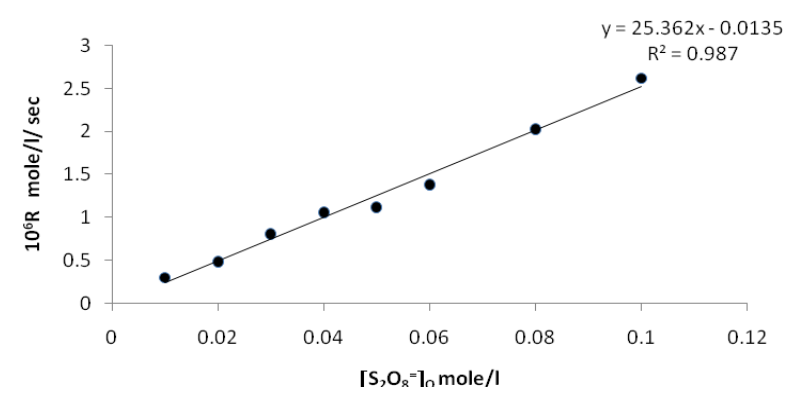

Figure 9. Rate dependence on $\left[\mathrm{S}_{2} \mathrm{O}_{8}{ }^{{ }^{\circ}}\right]_{\mathrm{o}}$ at $70{ }^{\circ} \mathrm{C}$

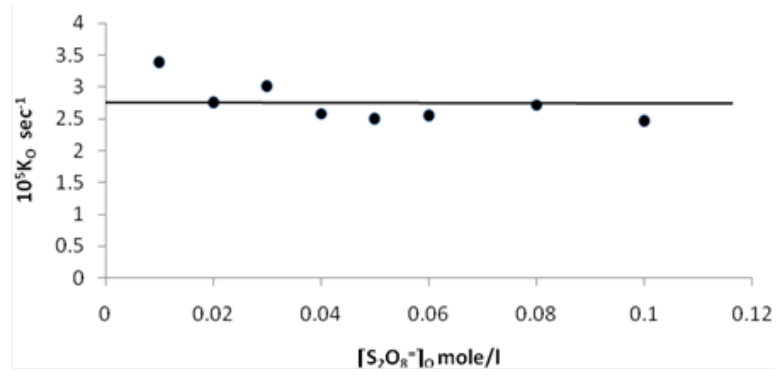

Figure 10. Plot of the observed rate constant Ko against $\left[\mathrm{S}_{2} \mathrm{O}_{8}{ }^{\circ}\right]_{\mathrm{o}}$ at $70{ }^{\circ} \mathrm{C}$

Table 6. Peroxydisulphate dependence : $\left[\mathrm{AgNO}_{3}\right]_{0}=\left[\mathrm{CuSO}_{4}\right]_{0}=$ $0.01 \mathrm{~mole} / 1 \mathrm{Temp} .70^{\circ} \mathrm{C}$

\begin{tabular}{|c|c|c|c|}
\hline $\begin{array}{c}{\left[\mathrm{S}_{2} \mathrm{O}_{8}{ }^{2-}\right]_{\mathrm{o}}} \\
\mathrm{mole} / \mathrm{l}\end{array}$ & $\begin{array}{c}{\left[\mathrm{S}_{2} \mathrm{O}_{8}{ }^{2-}\right]_{\text {Aver }}} \\
\mathrm{mole} / 1\end{array}$ & $\begin{array}{c}10^{6} \mathrm{R} \\
\mathrm{mole} / 1 / \mathrm{sec}\end{array}$ & $\begin{array}{c}10^{5} \mathrm{k}_{\mathrm{o}} \\
\mathrm{sec}^{-1}\end{array}$ \\
\hline 0.01 & 0.00436 & 0.7073 & 22.39 \\
\hline 0.02 & 0.00879 & 1.6521 & 21.36 \\
\hline 0.03 & 0.01137 & 2.5573 & 24.59 \\
\hline 0.04 & 0.01517 & 3.3283 & 24.89 \\
\hline 0.05 & 0.02656 & 3.4719 & 17.23 \\
\hline 0.06 & 0.03310 & 4.0438 & 16.12 \\
\hline 0.08 & 0.05549 & 4.1667 & 8.90 \\
\hline 0.1 & 0.05837 & 6.5969 & 14.14 \\
\hline
\end{tabular}

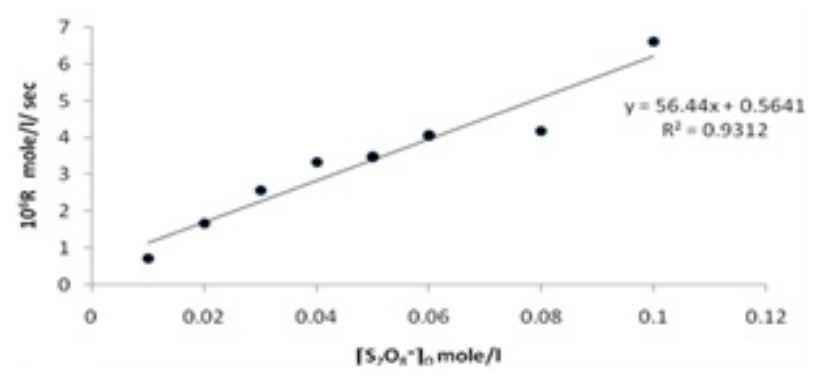

Figure 11. Rate dependence on $\left[\mathrm{S}_{2} \mathrm{O}_{8}{ }^{\circ}\right]_{0}$ at $70{ }^{\circ} \mathrm{C}$ 


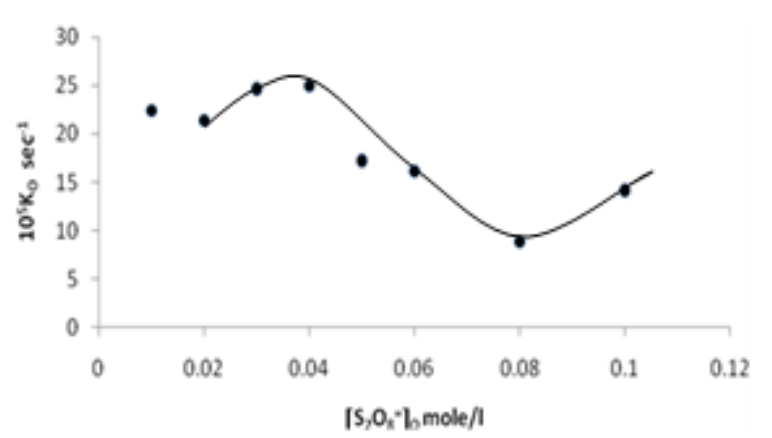

Figure 12. Plot of the observed rate constant Ko against $\left[\mathrm{S}_{2} \mathrm{O}_{8}{ }^{-}\right]_{\mathrm{o}}$ at $70{ }^{\circ} \mathrm{C}$

Figures (7), (9), and (11) show the linearity of the initial peroxydisulphate concentration $\left[\mathrm{S}_{2} \mathrm{O}_{8}{ }^{2-}\right]_{\mathrm{o}}$ with the rate $(\mathrm{R})$ for the three systems, so the rate can be expressed by the following equation $: \mathrm{R}=\mathrm{k}_{\mathrm{o}}\left[\mathrm{S}_{2} \mathrm{O}_{8}{ }^{2-}\right]_{\mathrm{o}}$. Also, it is obvious from figures (8) and (10) that the relation is linear and parallel to the concentration axis giving a graphical mean of $2.8 \times 10^{-5}$ $\mathrm{sec}^{-1}$ in case of $\mathrm{Ag}^{+}$ion and $2.7 \times 10^{-5} \mathrm{sec}^{-1}$, in case of $\mathrm{Cu}^{2+}$ ion . Therefore we conclude that the values of $\mathrm{k}_{\mathrm{o}}$ were found to be independent of peroxydisulphate concentration, so the reaction is first order in $\left[\mathrm{Ag}^{+}\right]$and $\left[\mathrm{Cu}^{2+}\right]$ and zero order in $\left[\mathrm{S}_{2} \mathrm{O}_{8}{ }^{2-}\right]$. In the case of the system $\left[\mathrm{Ag}^{+}+\mathrm{Cu}^{2+}\right]$ (figure (12)), the relation is not linear and that means the order of the reaction with respect to peroxydisulphate is unknown.

Table 7. $\left[\mathrm{S}_{2} \mathrm{O}_{8}{ }^{=}\right]=\left[\mathrm{Ag}^{+}\right]=\left[\mathrm{Cu}^{++}\right]=\left[\mathrm{Ag}^{+}+\mathrm{Cu}^{++}\right]=0.01 \mathrm{~mole} / 1$ $\mathrm{Temp} 70^{\circ} \mathrm{C}$

\begin{tabular}{|c|c|c|c|c|}
\hline & None(7) & $\mathrm{Cu}^{2+}$ & $\mathrm{Ag}^{+}$ & $\begin{array}{c}\mathrm{Ag}^{+}+ \\
\mathrm{Cu}^{2+}\end{array}$ \\
\hline $\begin{array}{c}10^{6} \mathrm{R} \\
\mathrm{mole} / \\
1 / \mathrm{sec}\end{array}$ & 0.2219 & 0.2986 & 0.3000 & 0.7073 \\
\hline $\begin{array}{c}10^{5} \mathrm{k}_{\mathrm{o}} \\
\mathrm{sec}^{-1}\end{array}$ & 2.64 & 3.39 & 3.41 & 2.76 \\
\hline
\end{tabular}

Table (7) includes a summary of the values of $(\mathrm{R})$ and $\left(\mathrm{k}_{\mathrm{o}}\right)$ for the catalytic and the co-catalytic thermal decomposition of potassium peroxydisulphate at $70{ }^{\circ} \mathrm{C}$. The above findings showed that the copper ion was much less efficient than the silver ion as catalyst for the thermal decomposition of peroxydisulphate. Finally, we can deduce that the catalytic influence of the different systems used in the thermal decomposition of peroxydisulphate is in the following order: co-catalyst $>\mathrm{Ag}^{+}>\mathrm{Cu}^{2+}$.

\section{REFERENCES}

[1] Morgan, J. L, Christ, R. H, (1927). J. Amer. Chem. Soc, 49, $338-961$.

[2] Fronaeus, S, Ostman, (1955) .C.O, Acta. Chem. Scand, 9, 902.

[3] Kolthoff, I.M, Miller, I.K, (1951). J. Amer.Chem. Soc, 73, 3055 .

[4] Green, L, Mason, D.O, (1910).J. Chem. Soc, 97, 2083.

[5] Levr, M.G, Migliorini, E, and Gazz,A, (1963). Chim Ltal, 36(ii), 599.

[6] Bawn,C. E, Margersion, D,(1955) Trans. Fraday.Soc,51, 925.

[7] Abualreish, M.J, (2008). Material Science Research India, $5(2), 261$

[8] Bartlett, P.D,Cotman, J.D., (1949).J. Amer.Chem. Soc., 71, 1419.

[9] Vasudeva,W.C, Ph.D thesis, (1969). Fac. of Science, U. Of $\mathrm{K}$.

[10] Rosin, J. "Reagents Chemicals and standards, (1946). D. van Nostrand. CO. Inc. New. York, 2nd edition .P. 349.

[11] Chasi,K, etal, (1977) Bull.Chem.Soc. Japan, 50, 3049.

[12] Sethna, S.M, (1951) Chem.Rev, 49, 91.

[13] Benzvi, E, Allen, T.J, (1961) J. Amer.Chem. Soc., 83, 4352. 